\title{
Production of Hydrogen: Photocatalytic Decomposition of Dimethyl Ether over Metal-Promoted $\mathrm{TiO}_{2}$ Catalysts
}

\author{
Gyula Halasi, Gábor Schubert, Frigyes Solymosi \\ MTA-SZTE Reaction Kinetics and Surface Chemistry Research Group, Szeged, Hungary \\ Email: fsolym@chem.u-szeged.hu
}

Received 12 April 2014; revised 16 May 2014; accepted 23 May 2014

Copyright (C) 2014 by authors and Scientific Research Publishing Inc. This work is licensed under the Creative Commons Attribution International License (CC BY). http://creativecommons.org/licenses/by/4.0/ c) (i) Open Access

\section{Abstract}

The photo-induced vapor-phase decomposition of dimethyl ether was investigated on Pt metals deposited on pure and $\mathrm{N}$-doped $\mathrm{TiO}_{2}$. Infrared spectroscopic measurements revealed that adsorption of dimethyl ether on $\mathrm{TiO}_{2}$ samples underwent partial dissociation to methoxy species. Illumination of the $\left(\mathrm{CH}_{3}\right)_{2} \mathrm{O}-\mathrm{TiO}_{2}$ and $\left(\mathrm{CH}_{3}\right)_{2} \mathrm{O}-\mathrm{M} / \mathrm{TiO}_{2}$ systems led to the conversion of methoxy into adsorbed formate. In the case of metal-promoted $\mathrm{TiO}_{2}$ catalysts, $\mathrm{CO}$ bonded to the metals was also detected. Pure titania exhibited a very little photoactivity. Deposition of Pt metals on $\mathrm{TiO}_{2}$ markedly enhanced the extent of photocatalytic decomposition of dimethyl ether to give $\mathrm{H}_{2}$ and $\mathrm{CO}_{2}$ as the major products. A small amount of $\mathrm{CO}$ and methyl formate was also identified in the products. The most active metal was the $\mathrm{Rh}$ followed by Pd, Ir, Pt and $\mathrm{Ru}$. When the bandgap of $\mathrm{TiO}_{2}$ was lowered by $\mathrm{N}$-doping, the photocatalytic activity of metal/ $\mathrm{TiO}_{2}$ catalysts appreciably increased. The effect of metals was explained by a better separation of charge carriers induced by illumination and by enhanced electronic interaction between metal nanoparticles and $\mathrm{TiO}_{2}$.

\section{Keywords}

Dimethyl Ether, Photocatalytic Decomposition, Production of Hydrogen, $\mathrm{TiO}_{2}, \mathrm{Pt}$ Metals, Doping $\mathrm{TiO}_{2}$ with $\mathrm{N}$

\section{Introduction}

The production of $\mathrm{H}_{2}$, with a small amount of $\mathrm{CO}$, is an important project for heterogeneous catalysis. In principle, the decomposition of methane and hydrocarbons seems to be a suitable process, but the carbon formed poisons the catalyst in early phase of the reaction [1]-[3]. More frequently used sources of $\mathrm{H}_{2}$ are ethanol, me-

How to cite this paper: Halasi, Gy., et al. (2014) Production of Hydrogen: Photocatalytic Decomposition of Dimethyl Ether over Metal-Promoted $\mathrm{TiO}_{2}$ Catalysts. American Journal of Analytical Chemistry, 5, 455-466. 
thanol and formic acid [4] [5]. For the generation of $\mathrm{H}_{2}$, almost free of $\mathrm{CO}$ formic acid is proved to be the more suitable compound [6]-[11]. However, the decomposition of all these compounds occurs at relatively high temperatures at 473 - $673 \mathrm{~K}$ even on the most active Pt metals. Illumination of the substrat-catalyst system, however, initiates their decomposition at room temperature [12]-[14]. The primary aim of the present work is to examine the photocatalytic decomposition of dimethyl ether (DME) on $\mathrm{TiO}_{2}$-supported Pt metals, and to explore the best experimental conditions for the production of hydrogen. Attention is paid to the identification of surface compounds formed during the illumination, to the effect of water and to the photocatalytic reaction in the visible light. Although the thermal catalytic decomposition of DME has been the subject of several studies [15]-[25], this is the first work dealing with the photocatalytic decomposition of DME. Note that the H/C and H/O ratios are the same as in the ethyl alcohol, which is the most frequently used compound for the production of hydrogen.

DME is emerging as a replacement for diesel fuel due to its low $\mathrm{NO}_{\mathrm{x}}$ emission, and near-zero smoke compared with traditional diesel fuels [26] [27]. DME, which was pointed out recently by Oláh [28], besides being the excellent transportation fuel, also allows storage of hydrogen and thus energy. As many important chemicals can be prepared from DME, it is perspicuous that its reactions have been the subject of the extensive research. This includes its combustion, selective oxidation to light olefins and formaldehyde, and transformation to hydrocarbons [28] [29].

\section{Experimental}

\subsection{Methods}

Photocatalytic reaction was followed in the same way as described in our previous papers [14]. We used a $15 \mathrm{~W}$ germicide lamp (type GCL 307T5L/CELL, Lighttech Ltd., Hungary), which emits predominantly in the wavelength range of $250-440 \mathrm{~nm}$, its maximum intensity is at $254 \mathrm{~nm}$. For the visible photocatalytic experiments another type of lamp was used (Lighttech GCL 307T5L/GOLD) with 400 - $640 \mathrm{~nm}$ wavelength range and two maximum intensities at 453 and $545 \mathrm{~nm}$. Note that this lamp also emits below $400 \mathrm{~nm}$. The approximate light intensity at the catalyst films is $3.9 \mathrm{~mW} / \mathrm{cm}^{2}$ for the germicide lamp and $2.1 \mathrm{~mW} / \mathrm{cm}^{2}$ for the other lamp. The photoreactor (volume: $670 \mathrm{ml}$ ) consists of two concentric quartz glass tubes fitted one into the other and a centrally positioned lamp. It is connected to a gas-mixing unit serving for the adjustment of the composition of the gas or vapor mixtures to be photolyzed in situ. The carrier gas was Ar, which was mixed with DME ( 1.5\%, 330 $\mu \mathrm{mol})$. The DME/water-containing Ar flow entered the reactor through an externally heated tube to avoid condensation. The gas-mixture was circulated by a diaphragm pump. The reaction products were analyzed with a HP 5890 gas chromatograph equipped with PORAPAK Q and PORAPAK S packed columns. The sampling loop of the GC was $500 \mu$ l. The amount of all products was related to this loop. The conversion of DME was mainly calculated taking into account the amount of DME consumed.

For FTIR studies a mobile IR cell housed in a metal chamber was used [14]. Samples were illuminated by the full arc of a Hg lamp (LPS-220, PTI) outside the IR sample compartment. The filtered light passed through a high-purity $\mathrm{CaF}_{2}$ window into the cell. Infrared spectra were recorded with a Biorad (Digilab. Div. FTS 155) instrument. All the spectra presented in this study are difference spectra. The surface area of the catalysts was determined by BET method with $\mathrm{N}_{2}$ adsorption at $\sim 100 \mathrm{~K}$. The dispersion of metals was determined by the adsorption of $\mathrm{H}_{2}$ at room temperature.

\subsection{Materials}

$\mathrm{TiO}_{2}$ of different origins was used: Hombikat, UV 100 (pure anatase, $300 \mathrm{~m}^{2} / \mathrm{g}$ ), $\mathrm{TiO}_{2}$ nanowire $(60 \mathrm{~m} / \mathrm{g})$ and nanotube $\left(40 \mathrm{~m}^{2} / \mathrm{g}\right)$. The synthesis of the last two compounds is described elsewhere [30]. For the preparation of N-doped samples $\mathrm{TiO}_{2}$ was reacted with $\mathrm{NH}_{3}$ [31] [32]. Titanium tetrachloride was used as a precursor. After several steps the $\mathrm{NH}_{3}$-treated $\mathrm{TiO}_{2}$ slurry was vacuum dried at $353 \mathrm{~K}$ for $12 \mathrm{hr}$, followed by calcination at $723 \mathrm{~K}$ in flowing air for $3 \mathrm{hr}$. This $\mathrm{TiO}_{2}$ is noted with "SX". The surface area of $\mathrm{TiO}_{2}$ prepared in this way is $265 \mathrm{~m}^{2} / \mathrm{g}$ and that of $\mathrm{N}$-doped oxide is $79 \mathrm{~m}^{2} / \mathrm{g}$. The nitrogen content of this sample is $2.9 \%$. The bandgaps of these $\mathrm{TiO}_{2}$ samples have been evaluated in our previous work [14]. We obtained $3.02 \mathrm{eV}$ for pure $\mathrm{TiO}_{2}$ and $1.98 \mathrm{eV}$ for $\mathrm{N}$-doped $\mathrm{TiO}_{2}$. Metal-promoted $\mathrm{TiO}_{2}$ samples were prepared by impregnating pure or doped $\mathrm{TiO}_{2}$ with the solu- 
tion of metal compounds to yield a nominal $2 \mathrm{wt} \%$ metal. The following salts of Pt metals were used: $\mathrm{Pd}\left(\mathrm{NO}_{3}\right)_{2}$, $\mathrm{H}_{2} \mathrm{IrCl}_{6}, \mathrm{RhCl}_{3} \cdot 3 \mathrm{H}_{2} \mathrm{O}, \mathrm{H}_{2} \mathrm{PtCl}_{6} \cdot 6 \mathrm{H}_{2} \mathrm{O}$ and $\mathrm{RuCl}_{3} \cdot 3 \mathrm{H}_{2} \mathrm{O}$. For IR studies the samples were pressed in self-supporting wafers $\left(30 \times 10 \mathrm{~mm} \sim 10 \mathrm{mg} / \mathrm{cm}^{2}\right)$. For photocatalytic measurements the sample (70 - $80 \mathrm{mg}$ ) was sprayed onto the outer side of the inner tube from aqueous suspension. The surface of the catalyst film was $168 \mathrm{~cm}^{2}$. The catalysts were oxidized and reduced at $573 \mathrm{~K}$ in the IR cell or in the catalytic reactor for $1 \mathrm{hr}$. DME was the product of Gerling Holz Co. with purity of 99.9\%.

\section{Results}

\subsection{FTIR Study of Photolysis of DME}

The primary aim of IR study is to ascertain the development of adsorbed complexes formed on the effect of illumination on $\mathrm{TiO}_{2}$, and to establish the influence of metal deposition on these features. Exposing pure $\mathrm{TiO}_{2}$ to DME at $300 \mathrm{~K}$ resulted in a development of intense absorption bands in the C-H stretching region at 2950, 2921, 2878, 2842 and $\sim 2830 \mathrm{~cm}^{-1}$ (Figure 1). In the low frequency range strong bands appeared at 1459, 1253, 1159 and $\sim 1063 \mathrm{~cm}^{-1}$. Weaker bands or shoulder were also traced at $\sim 1592$ and $\sim 1384 \mathrm{~cm}^{-1}$. Illumination of the adsorbed DME caused only very slight changes in the high frequency range, but led to the slow attenuation of the bands at 1459 and $1253 \mathrm{~cm}^{-1}$. At the same time the absorption peaks at $\sim 1585$ and $1366 \mathrm{~cm}^{-1}$ increased in intensity. These spectral features were also observed on the IR spectra of metal/ $/ \mathrm{TiO}_{2}$ samples (Figure 2). In the high frequency range a pair of strong absorption bands at 2948 - 2952 and $2833-2838 \mathrm{~cm}^{-1}$ of almost same intensity became the dominant spectral features for all $\mathrm{M} / \mathrm{TiO}_{2}$ catalysts. In the low frequency range the absorption features at $\sim 1458,1253,1153$ and $1047-1056 \mathrm{~cm}^{-1}$ were found. We obtained similar spectral features for $\mathrm{Ir} / \mathrm{TiO}{ }_{2}$ (not presented). The effect of the illumination on the IR spectra was almost the same as observed for pure $\mathrm{TiO}_{2}$. The difference was the appearance of a shoulder at $2936 \mathrm{~cm}^{-1}$ and the development of an intense CO band between $2001-2078 \mathrm{~cm}^{-1}$, which grew slightly with the progress of illumination. In the low frequency range new strong absorption features appeared at $\sim 1570$ - 1574 and $\sim 1357 \mathrm{~cm}^{-1}$. IR bands observed on different samples and their assignments are presented in Table 1.

\subsection{Catalytic Studies in UV Light}

The photocataytic decomposition of DME has been investigated on different $\mathrm{TiO}_{2}$ samples. Whereas DME does not decompose at $300 \mathrm{~K}$ on pure $\mathrm{TiO}_{2}$, illumination induced the occurrence of the reaction to give $\mathrm{H}_{2}$ and $\mathrm{CO}_{2}$.

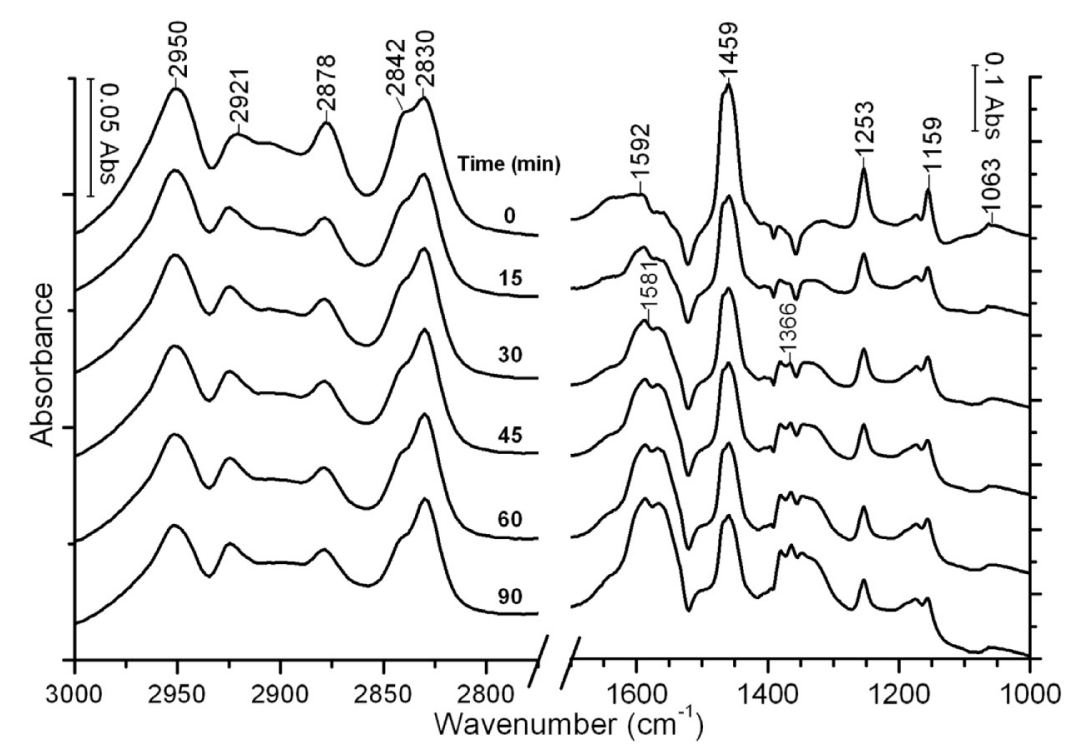

Figure 1. Effects of illumination time on the FTIR spectra of adsorbed dimethyl ether on $\mathrm{TiO}_{2}$ (Hombikat). 


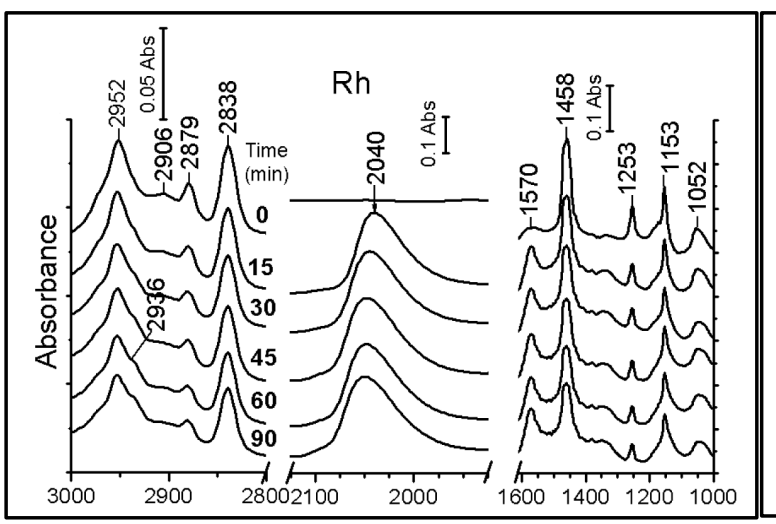

(a)

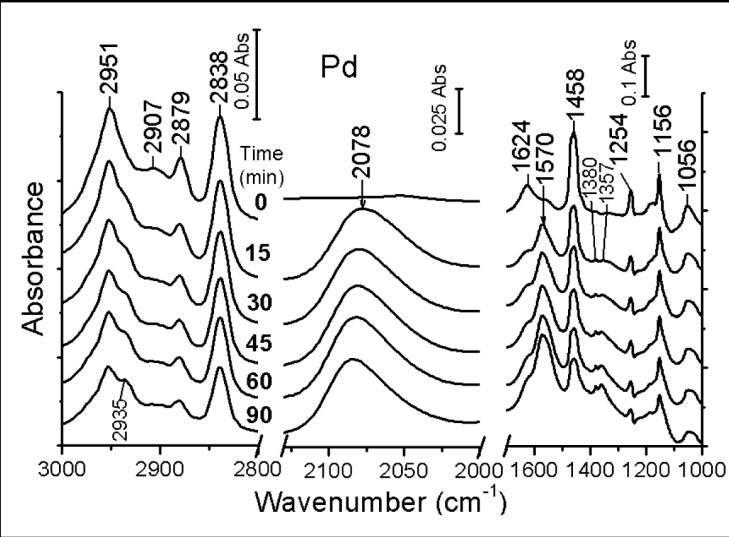

(c)

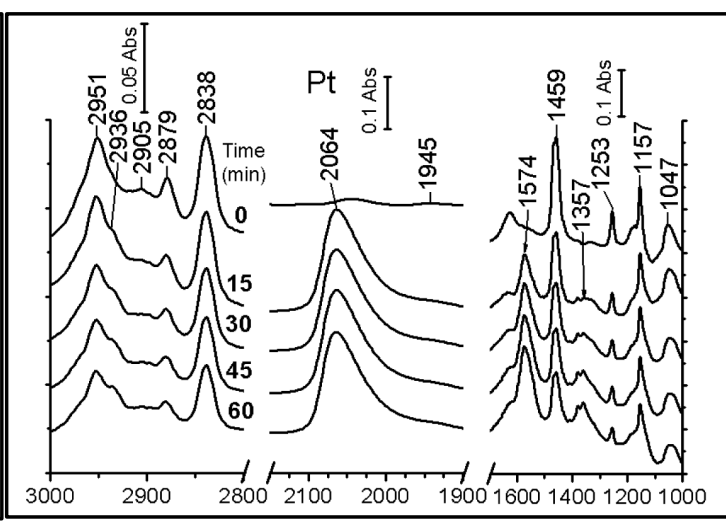

(b)

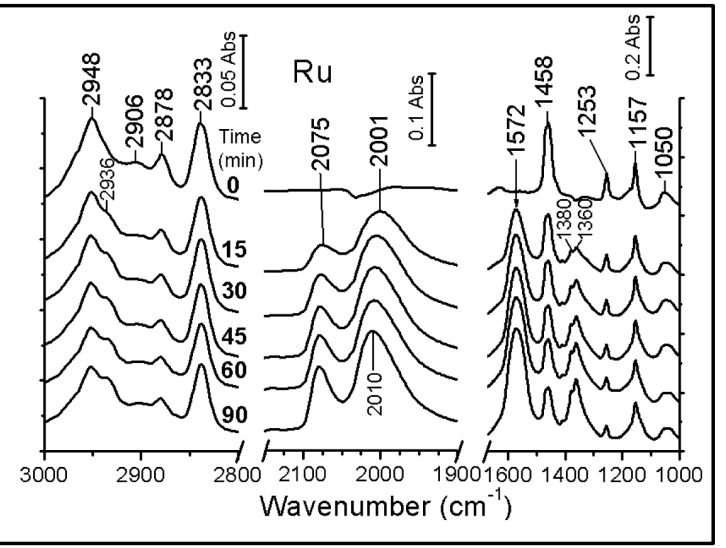

(d)

Figure 2. Effects of illumination time on the FTIR spectra of adsorbed dimethyl ether on $\mathrm{Rh} / \mathrm{TiO}_{2}(\mathrm{a}), \mathrm{Pt} / \mathrm{TiO}{ }_{2}$ (b), $\mathrm{Pd} / \mathrm{TiO}_{2}$ (c) and $\mathrm{Ru} / \mathrm{TiO}_{2}$ (d) at $300 \mathrm{~K}$.

Table 1. Characteristic absorption bands $\left(\mathrm{cm}^{-1}\right)$ following the adsorption of dimethyl ether, methanol and formic acid on various solids.

\begin{tabular}{|c|c|c|c|c|c|c|c|}
\hline $\begin{array}{l}\text { Vibrational } \\
\text { mode }\end{array}$ & $\begin{array}{l}\operatorname{DME}(\mathrm{g}) \\
{[33][34]}\end{array}$ & $\begin{array}{c}\mathrm{DME}(\mathrm{a}) \text { on } \\
\mathrm{Al}_{2} \mathrm{O}_{3} \text { at } \\
150 \mathrm{~K}[34]\end{array}$ & $\begin{array}{c}\mathrm{DME}(\mathrm{a}) \text { on } \\
\mathrm{CeO}_{2} \text { at } \\
300 \mathrm{~K} \text { [28] }\end{array}$ & $\begin{array}{c}\mathrm{CH}_{3} \mathrm{O}_{(\mathrm{a})} \text { on } \mathrm{TiO}_{2} \\
\text { at } 300 \mathrm{~K}[35]\end{array}$ & $\begin{array}{c}\mathrm{HCOO}_{(\mathrm{a})} \\
\text { on } \mathrm{TiO}_{2} \text { at } \\
300 \mathrm{~K}[14]\end{array}$ & $\begin{array}{c}\mathrm{DME} \text { on } \mathrm{TiO}_{2} \\
\text { at } 300 \mathrm{~K} \\
\text { [present study] }\end{array}$ & $\begin{array}{c}\mathrm{DME} \text { on } \mathrm{Rh} / \mathrm{TiO}_{2} \\
\text { at } 300 \mathrm{~K} \\
\text { [present study] }\end{array}$ \\
\hline$v_{\mathrm{a}}\left(\mathrm{CH}_{3}\right)$ & $\begin{array}{l}2996 \\
2925\end{array}$ & $\begin{array}{l}2984 \\
2922\end{array}$ & 2953 & $\begin{array}{l}2965 \\
2930\end{array}$ & 2958 & $\begin{array}{l}2950 \\
2921\end{array}$ & $\begin{array}{l}2952 \\
2906\end{array}$ \\
\hline$v_{\mathrm{s}}\left(\mathrm{CH}_{3}\right)$ & 2817 & 2821 & 2841 & 2830 & 2886 & 2878 & 2879 \\
\hline $2 \delta\left(\mathrm{CH}_{3}\right)$ & 2887 & 2890 & 2884 & & & 2842 & 2838 \\
\hline$v_{\mathrm{a}}(\mathrm{OCO})$ & & & & & 1552 & & \\
\hline$v_{\mathrm{s}}(\mathrm{OCO})$ & & & & & 1377 & & \\
\hline$\delta_{\text {as }}\left(\mathrm{CH}_{3}\right)$ & 1470 & 1477 & 1436 & 1462 & & 1459 & 1458 \\
\hline$\delta_{\mathrm{s}}\left(\mathrm{CH}_{3}\right)$ & 1456 & 1459 & & 1436 & & & \\
\hline$\gamma\left(\mathrm{CH}_{3}\right)$ & $\begin{array}{l}1244 \\
1179\end{array}$ & $\begin{array}{l}1252 \\
1116\end{array}$ & $\begin{array}{l}1229 \\
1159\end{array}$ & 1151 & & $\begin{array}{l}1253 \\
1159\end{array}$ & $\begin{array}{l}1253 \\
1153\end{array}$ \\
\hline$v_{\text {as }}(\mathrm{CO})$ & 1102 & 1092 & 1066 & 1125 & 1277 & 1063 & 1052 \\
\hline
\end{tabular}

(g) gaseous; (a) adsorbed. 
However even on the most effective $\mathrm{TiO}_{2}$ (Hombikat) the extent of the decomposition was very low, about $\sim 2 \%$ $3 \%$, in $210 \mathrm{~min}$. The photocatalytic effect of $\mathrm{TiO}_{2}$ nanowire and nanotubes was also tested: we obtained a similar low photoactivity.

The deposition of Pt metals on $\mathrm{TiO}_{2}$ (Hombikat) markedly enhanced its photoactivity. In Figure 3, we displayed the conversion of DME and the amount of products formed on various catalysts as a function of illumination time. On the most active $\mathrm{Rh} / \mathrm{TiO}_{2}$, the conversion of the decomposition of DME attained $\sim 22 \%$ in 210 min. On the less active $\mathrm{Ru} / \mathrm{TiO}_{2}$ it was only $\sim 6.5 \%$. The main products were $\mathrm{H}_{2}$ and $\mathrm{CO}_{2}$. A small amount of $\mathrm{CO}$ and methyl formate was also formed. A trace of formaldehyde was also detected. The $\mathrm{CO} / \mathrm{H}_{2}$ ratio varied between $\sim 0.023-0.044$. The formation of methyl formate deserves a special attention. Its amount increased with the illumination time (Figure 4(a)). The largest quantity was measured for $\mathrm{Rh} / \mathrm{TiO}_{2}$ and the lowest one for $\mathrm{Pt} / \mathrm{TiO}_{2}$. When its amount was related to that of $\mathrm{H}_{2}$ produced, we obtained the highest value for $\mathrm{Ru} / \mathrm{TiO}_{2}$. The ratio of methyl formate/ $\mathrm{H}_{2}$ slowly decreased with the duration of illumination (Figure 4(b)). Some important data for the photocatalytic decomposition of DME are presented in Table 2. Based on the conversion data, the activity order of metals was as follows: $\mathrm{Rh}, \mathrm{Pd}$, Ir, $\mathrm{Pt}$ and $\mathrm{Ru}$. When the rate of $\mathrm{H}_{2}$ production is related to the dispersity of the metals, we obtained slightly different order: Pt, Rh, Pd, Ir and Ru.

In order to judge the contribution of thermal effect for the photoreaction, we also examined the thermal reaction on selected catalysts. A measurable reaction on $\mathrm{Pt} / \mathrm{TiO}_{2}$ and $\mathrm{Rh} / \mathrm{TiO}_{2}$ was observed only at $523 \mathrm{~K}$. Attaching a thin thermocouple in the catalyst layer indicated only a temperature rise of only a few degrees during illumination. The results of these control experiments lead us to exclude the contribution of thermal effects to the photodecomposition of DME induced by illumination.

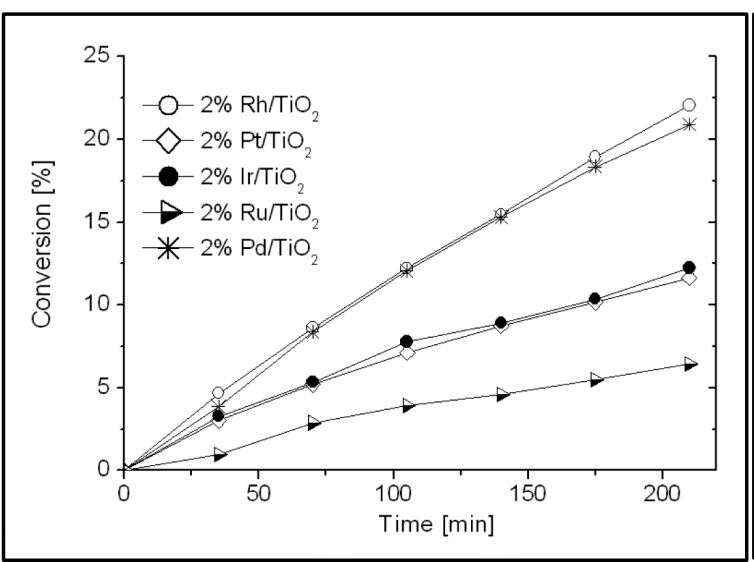

(a)

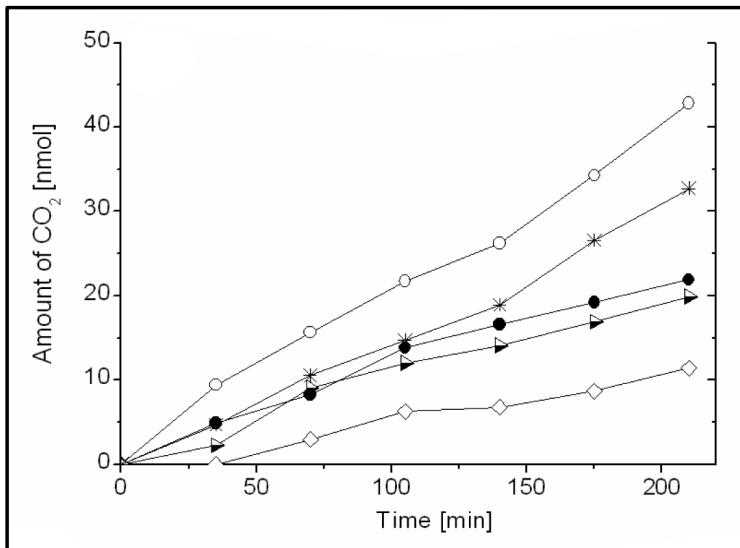

(c)

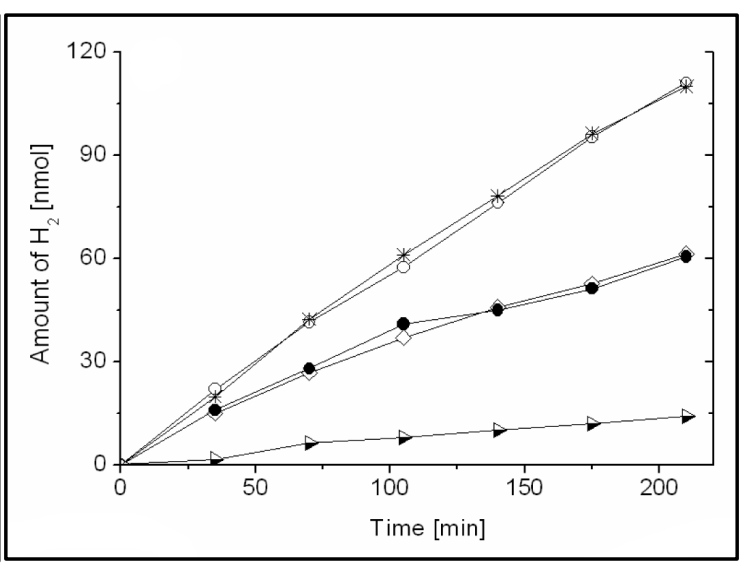

(b)

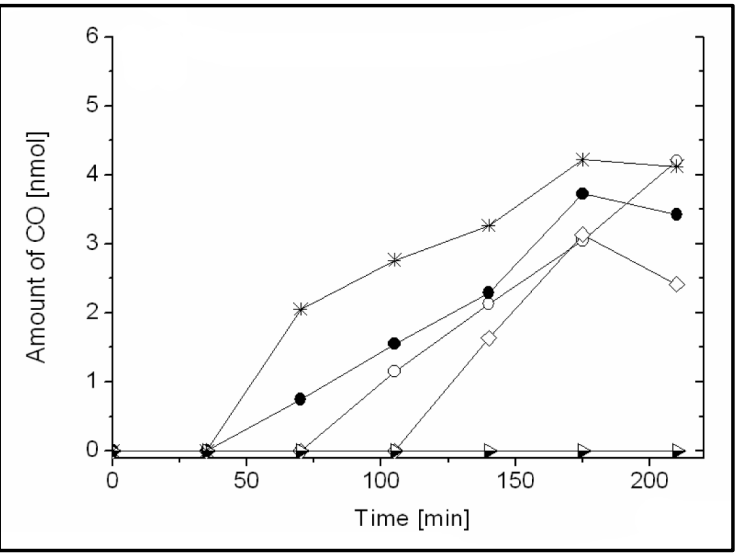

(d)

Figure 3. Effects of different Pt metals deposited on $\mathrm{TiO}_{2}$ (Hombikat) on the photocatalytic decomposition of dimethyl ether. Conversion (a), formation of $\mathrm{H}_{2}$ (b), $\mathrm{CO}_{2}$ (c) and $\mathrm{CO}$ (d). 
Table 2. Some characteristic data for the photolysis of DME on metal-promoted $\mathrm{TiO}_{2}$.

\begin{tabular}{ccccccc}
\hline Samples & Dispersion (\%) & Conversion (\%, 210 min) & $\mathrm{TOF}_{\mathrm{H}_{2}}$ & Methyl formate (nmol, $210 \mathrm{~min})$ & $\mathrm{CO} / \mathrm{H}_{2}(210 \mathrm{~min})$ & $\mathrm{MF} / \mathrm{H}_{2}(210 \mathrm{~min})$ \\
\hline $2 \% \mathrm{Rh} / \mathrm{TiO}_{2}$ & 16 & 22.5 & 0.063 & 5.9 & 0.023 & 0.052 \\
$2 \% \mathrm{Pd} / \mathrm{TiO}_{2}$ & 26 & 21.0 & 0.042 & 4.2 & 0.039 & 0.042 \\
$2 \% \mathrm{Ir} / \mathrm{TiO}_{2}$ & 54 & 12.5 & 0.024 & 1.6 & 0.044 & 0.028 \\
$2 \% \mathrm{Pt} / \mathrm{TiO}_{2}$ & 13 & 12.0 & 0.096 & 0.4 & 0.039 & 0.007 \\
$2 \% \mathrm{Ru} / \mathrm{TiO}_{2}$ & 6 & 6.5 & 0.023 & 2.0 & 0 & 0.142 \\
\hline
\end{tabular}

$\mathrm{TOF}_{\mathrm{H}_{2}}=$ the amount of $\mathrm{H}_{2}$ formed in 210 min related to the number of metal atoms.

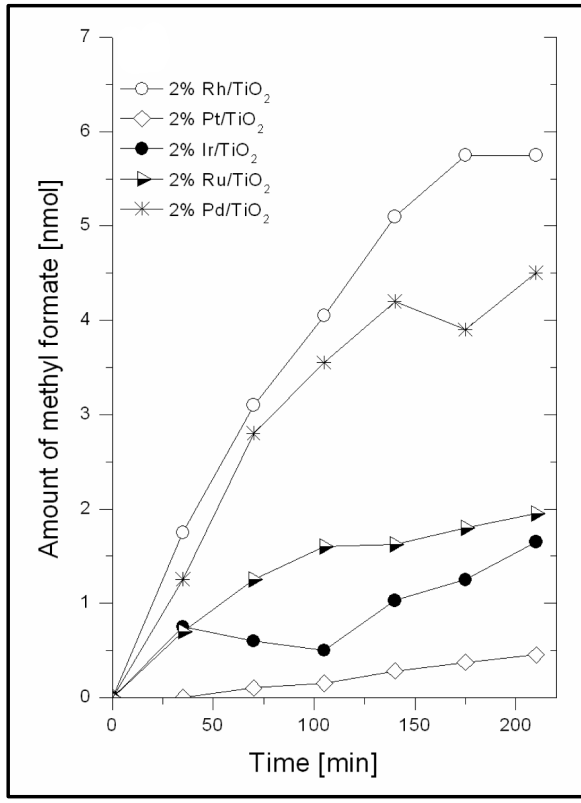

(a)

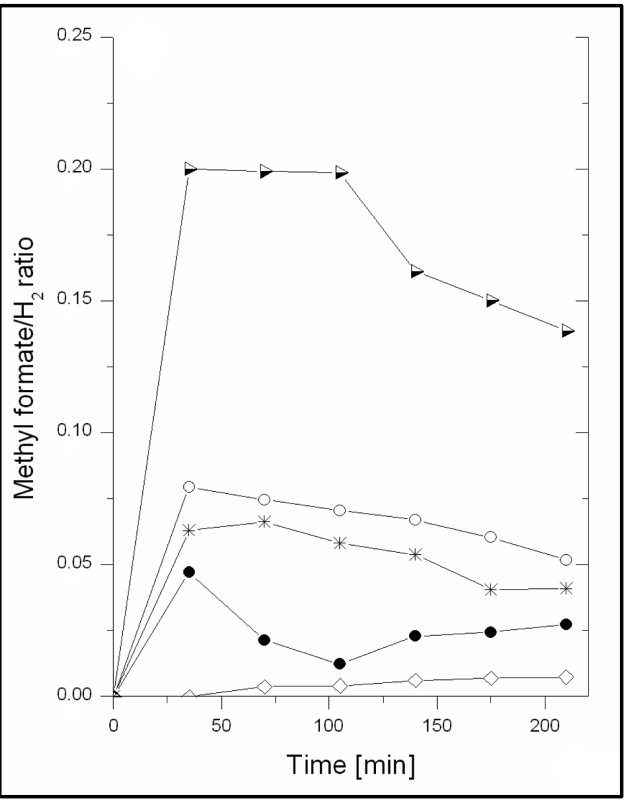

(b)

Figure 4. Effects of illumination time on the formation of methyl formate (a) and on the methyl formate $/ \mathrm{H}_{2}$ ratio (b) on $\mathrm{TiO}_{2}$-supported Pt metals.

The effect of illumination on the reforming of DME was also investigated. Water exerted a positive influence on the conversion of DME and it appreciably increased the amount of $\mathrm{H}_{2}$ formed. As the hydrolysis of DME to $\mathrm{CH}_{3} \mathrm{OH}$ occurs more easily on the acidic centers of $\mathrm{Al}_{2} \mathrm{O}_{3}$, some experiments have been performed in the presence of $\mathrm{Al}_{2} \mathrm{O}_{3}$. Adding $\mathrm{Al}_{2} \mathrm{O}_{3}$ to $\mathrm{Pd} / \mathrm{TiO}_{2}$ catalyst greatly enhanced the conversion of $\mathrm{DME}$ and the formation of $\mathrm{H}_{2}$. Table 3 contains some characteristic data.

\subsection{Catalytic Studies in Visible Light}

Some experiments have been performed in visible light. These measurements were carried out with $\mathrm{TiO}_{2}(\mathrm{SX})$, which possessed better performance compared to other $\mathrm{N}$-doped $\mathrm{TiO}_{2}$ [14]. As the surface area of $\mathrm{TiO}_{2}$ is markedly lowered by doping with $\mathrm{N}$, the data presented in Figure 5 are related to unit surface area. The results clearly show that whereas pure $\mathrm{TiO}_{2}$ exhibits very little activity in the visible light, the photoactivity of N-doped sample (SX) is appreciably higher. Similar features were experienced for metal-promoted $\mathrm{TiO}_{2}$. Figure 6 depicts the photocatalytic effects of three selected metals deposited on pure and $\mathrm{N}$-doped $\mathrm{TiO}_{2}(\mathrm{SX})$. A comparison immediately reveals that the photoactivity of the metals on N-doped sample is markedly higher than that of $\mathrm{M} / \mathrm{TiO} 2$ free of nitrogen. This is reflected in the conversion of DME and in the amounts of the products formed in the photo-induced decomposition. 
Table 3. Effects of $\mathrm{H}_{2} \mathrm{O}$ and $\mathrm{Al}_{2} \mathrm{O}_{3}$ on the product distribution of photocatalytic decomposition of DME on $\mathrm{Pd} / \mathrm{TiO}{ }_{2}$ samples. Data refer to reaction time of $210 \mathrm{~min}$.

\begin{tabular}{cccc}
\hline Samples & Conversion (\%) & $\mathrm{H}_{2}$ (nmol) & $\begin{array}{c}\mathrm{H}_{2} \text { formed related to the } \\
\text { amount of } \mathrm{Pd} / \mathrm{TiO}_{2}(\mathrm{nmol} / \mathrm{g})\end{array}$ \\
\hline $\mathrm{Pd} / \mathrm{TiO}_{2}$ & 22 & 110 & 1.69 \\
$\mathrm{Pd} / \mathrm{TiO}_{2}, \mathrm{DME}: \mathrm{H}_{2} \mathrm{O}(1: 1)$ & 20 & 155 & 2.15 \\
$\mathrm{Pd} / \mathrm{TiO}_{2}, \mathrm{DME}: \mathrm{H}_{2} \mathrm{O}(1: 3)$ & 16 & 180 & 2.52 \\
$\mathrm{Pd} / \mathrm{TiO}_{2}+\mathrm{Al}_{2} \mathrm{O}_{3}(1: 1), \mathrm{DME}: \mathrm{H}_{2} \mathrm{O}(1: 3)$ & 23 & 180 & 7.20 \\
\hline
\end{tabular}
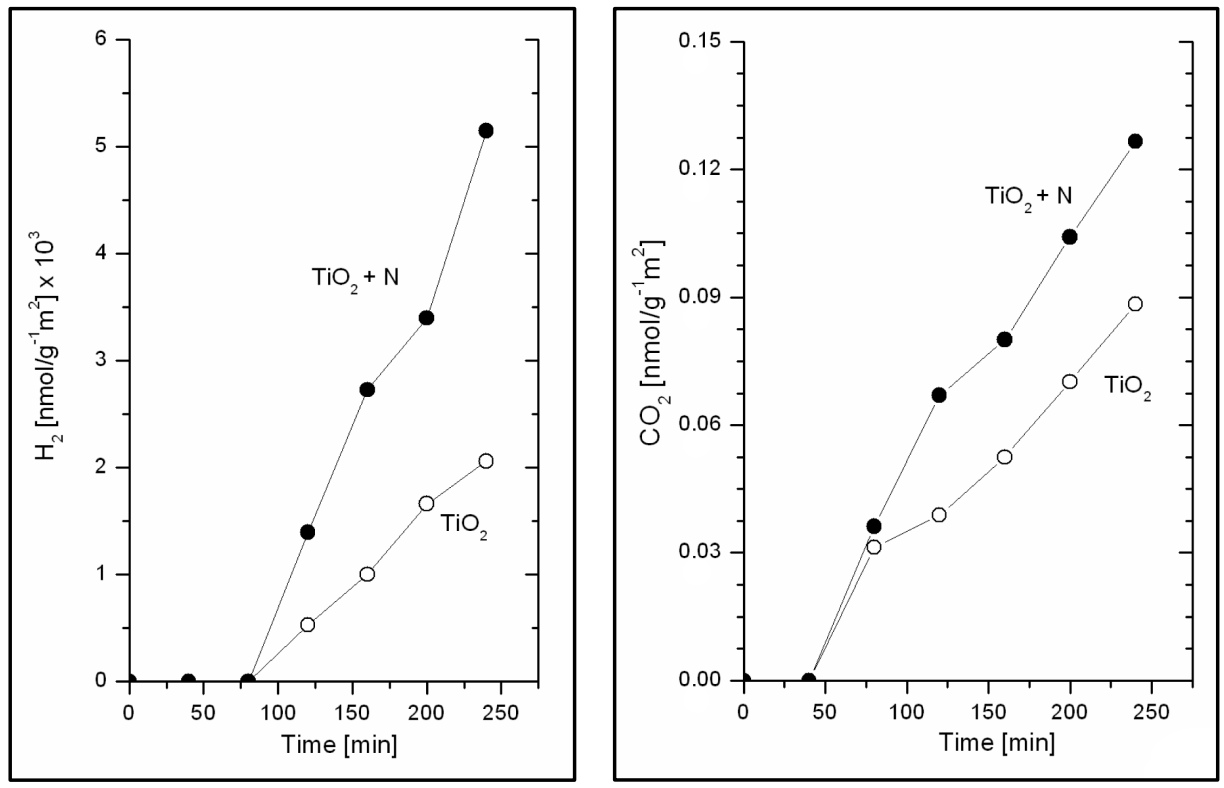

Figure 5. Photocatalytic decomposition of dimethyl ether on pure and $\mathrm{N}$-doped $\mathrm{TiO}_{2}$ samples (SX) in visible light.

\section{Discussion}

\subsection{IR Studies}

Adsorption of DME on $\mathrm{TiO}_{2}$ at $300 \mathrm{~K}$ produced several intense absorption bands in the IR spectra. Taking into account the results of previous studies their possible assignment is presented in Table 1 . In the high frequency range a pair of strong absorption bands at $\sim 2952$ and $2838 \mathrm{~cm}^{-1}$ of almost same intensity became the dominant spectral features for pure and metal-promoted $\mathrm{TiO}_{2}$ catalysts. These absorption bands are the characteristic vibration of molecularly bonded DME. The dissociation of $\mathrm{DME}$ to $\mathrm{CH}_{3} \mathrm{O}$ species is indicated by the appearance of another pair of bands at 2936 and $2879 \mathrm{~cm}^{-1}$. The intensities of all these bands underwent a slight attenuation as a result of illumination. A more striking effect of photolysis of adsorbed DME is the appearance of asymmetric stretch of formate bands at $\sim 1570 \mathrm{~cm}^{-1}$, and the development of CO band between $2000-2101 \mathrm{~cm}^{-1}$ on $\mathrm{TiO}_{2}$-supported metals. The fact that we observed the same spectral features for $\mathrm{TiO}_{2}$ and for $\mathrm{M} / \mathrm{TiO}_{2}$ samples indicates that both the adsorbed DME and the $\mathrm{CH}_{3} \mathrm{O}$ species are located on the $\mathrm{TiO}_{2}$ surface. The appearance of $\mathrm{CO}$ band in the IR spectra of metal/ $/ \mathrm{TiO}_{2}$ samples, however, suggests that the metals can initiate the decomposition of these compounds very likely resided at the metal/oxide interface. An interesting feature of the IR spectra is the absence of dicarbonyl species $\left(\mathrm{M}^{+}(\mathrm{CO})_{2}\right)$. This possible reason is that hydrogen formed in the photoreactions prevents the oxidative disruption of metal particles leading to the formation of $\mathrm{M}^{+}(\mathrm{CO})_{2}$ surface complex [36].

The formation of methoxy species suggests the breakage of one of the C-O bonds in the adsorbed DME 


$$
\left(\mathrm{CH}_{3}\right)_{2} \mathrm{O}_{(\mathrm{a})} \rightarrow \mathrm{CH}_{3} \mathrm{O}_{(\mathrm{a})}+\mathrm{CH}_{3(\mathrm{a})}
$$

As there it is no indication of the IR bands of adsorbed $\mathrm{CH}_{3}$ radical [37], it is very likely that the $\mathrm{CH}_{3}$ has been attached to the oxygen atom of $\mathrm{TiO}_{2}$ also yielding a $\mathrm{Ti}^{-} \mathrm{OCH}_{3}$ surface compound. Accordingly, instead of step (1), we can count with the reaction of DME with the $\mathrm{OH}$ groups of $\mathrm{TiO}_{2}$

$$
\left(\mathrm{CH}_{3}\right)_{2} \mathrm{O}_{(\mathrm{a})}+\mathrm{OH}_{(\mathrm{a})} \rightarrow 2 \mathrm{CH}_{3} \mathrm{O}_{(\mathrm{a})}+\mathrm{H}_{(\mathrm{a})}
$$

Illumination of adsorbed layer resulted in a slow attenuation of methoxy bands and the appearance of absorption features due to formate species. Its formation is described by the following elementary steps

$$
\begin{gathered}
\mathrm{CH}_{3} \mathrm{O}_{(\mathrm{a})} \rightarrow \mathrm{CH}_{2} \mathrm{O}_{(\mathrm{a})}+\mathrm{H}_{(\mathrm{a})} \\
\mathrm{CH}_{2} \mathrm{O}_{(\mathrm{a})}+\mathrm{OH}_{(\mathrm{a})} \rightarrow \mathrm{HCOO}_{(\mathrm{a})}+\mathrm{H}_{2(\mathrm{~g})}
\end{gathered}
$$

\subsection{Catalytic Studies}

DME proved to be very resistant towards illumination on $\mathrm{TiO}_{2}$. Deposition of Pt metals on the $\mathrm{TiO}_{2}$, however, enhanced its photoactivity, but the low reactivity of DME appeared on these catalysts, too. The effect of illumination can be explained by the donation of photoelectrons formed in the photo-excitation process

$$
\mathrm{TiO}_{2}+\mathrm{h} v \rightarrow \mathrm{h}^{+}+\mathrm{e}^{-}
$$

to the $\mathrm{CH}_{3} \mathrm{O}$ species:

$$
\mathrm{CH}_{3} \mathrm{O}_{(\mathrm{a})}+\mathrm{e}^{-} \rightarrow \mathrm{CH}_{3} \mathrm{O}_{(\mathrm{a})}^{\delta-}
$$

producing a more reactive negatively charged species, which is converted into adsorbed $\mathrm{CH}_{2} \mathrm{O}$ and $\mathrm{HCOO}$ (Equations (3) and (4)). However, even the photo-induced reaction occurred to only a very limited extent on pure $\mathrm{TiO}_{2}$, a finding which can be attributed to the fast recombination of the electrons and holes formed in the photo-excitation process (Equation (5)). The formation of $\mathrm{H}_{2}, \mathrm{CO}_{2}$ and $\mathrm{CO}$ suggests the occurrence of the reactions

$$
\begin{gathered}
\mathrm{CH}_{2} \mathrm{O}_{(\mathrm{a})}^{\delta-} \rightarrow \mathrm{CO}_{(\mathrm{a})}^{\delta-}+\mathrm{H}_{2(\mathrm{~g})} \\
\mathrm{HCOO}_{(\mathrm{a})}^{\delta-} \rightarrow \mathrm{CO}^{\delta-}{ }_{2(\mathrm{a})}+1 / 2 \mathrm{H}_{2(\mathrm{~g})} \\
\mathrm{CO}^{\delta-}{ }_{2(\mathrm{a})}+\mathrm{h}^{+} \rightarrow \mathrm{CO}_{2(\mathrm{~g})}
\end{gathered}
$$

An interesting and somewhat surprising result of the photocatalytic decomposition of DME is the formation of methyl formate. This compound has been considered as a precursor in the preparation of several materials [38]. Methyl formate is mainly synthesized by dehydrogenation of methanol over Cu-based catalyst at higher temperatures. However, recent works showed that it is also formed in the photocatalytic oxidation [39] and decomposition of methanol on polycrystalline $\mathrm{TiO}_{2}$ at room temperature [40]. Its production was markedly increased when Pt metals were deposited on $\mathrm{TiO}_{2}$ [40]. The highest yield of methyl formate was measured for $\mathrm{Pt} / \mathrm{TiO}_{2}$ (62.2) and the lowest one for $\mathrm{Ru} / \mathrm{TiO}_{2}$ (26.0). Recent studies performed under UHV conditions on preoxidized $\mathrm{TiO}_{2}(110)$ disclosed that methyl formate is produced from the photo-oxidation of methanol even at $\sim 200 \mathrm{~K}$ [41]. The finding that methyl formate is produced in the photocatalytic decomposition of DME further supports the idea that $\mathrm{CH}_{3} \mathrm{O}$ species is involved in its photoreaction The formation of methyl formate can be ascribed to the recombination of $\mathrm{CH}_{2} \mathrm{O}$ formed in the dissociation of $\mathrm{CH}_{3} \mathrm{O}$ (Equation (3)):

$$
2 \mathrm{CH}_{2} \mathrm{O}_{(\mathrm{a})} \rightarrow \mathrm{HCOOCH}_{3(\mathrm{a})}
$$

or by the reaction of $\mathrm{CH}_{2} \mathrm{O}$ with a further $\mathrm{CH}_{3} \mathrm{O}$ species:

$$
\mathrm{CH}_{2} \mathrm{O}_{(\mathrm{a})}+\mathrm{CH}_{3} \mathrm{O}_{(\mathrm{a})} \rightarrow \mathrm{HCOOCH}_{3(\mathrm{a})}+\mathrm{H}_{(\mathrm{a})}
$$

An appreciable increase in the extent of photolysis of DME was observed in the presence of $\mathrm{H}_{2} \mathrm{O}$, which can be attributed to the occurrence of the hydrolysis of DME, 


$$
\left(\mathrm{CH}_{3}\right)_{2} \mathrm{O}+\mathrm{H}_{2} \mathrm{O} \rightarrow 2 \mathrm{CH}_{3} \mathrm{OH}
$$

e.g. to the formation of more reactive $\mathrm{CH}_{3} \mathrm{OH}$. The addition of $\mathrm{H}_{2} \mathrm{O}$ to DME also lowered the extent of $\mathrm{CO}$ formation, very likely due to the occurrence of the water-gas shift reaction promoted by illumination. This was confirmed by a separate experiment. Mixing $\mathrm{Pd} / \mathrm{TiO}_{2}$ with $\mathrm{Al}_{2} \mathrm{O}_{3}$ further enhanced the formation of $\mathrm{H}_{2}$, which can be also ascribed to the promotion of the hydrolysis of DME to methanol.

The deposition of metals onto $\mathrm{TiO}_{2}$ greatly improved the photocatalytic effect of the $\mathrm{TiO}_{2}$. We assume that the $\mathrm{CH}_{3} \mathrm{O}$ species formed at the metal/TiO $\mathrm{Tin}_{2}$ interface is much more reactive than that located on $\mathrm{TiO}_{2}$. The promoting effect of Pt metals deposited on $\mathrm{TiO}_{2}$ is generally explained by the better charge carrier separation induced by illumination [12] [13] [42]. In addition we assume that the occurrence of an electronic interaction between n-type $\mathrm{TiO}_{2}$ and $\mathrm{Pt}$ metals is also important. The role of the electronic interaction between metals and $\mathrm{TiO}_{2}$ has been first demonstrated in the catalytic decomposition of formic acid on $\mathrm{Ni}$ deposited on pure and doped $\mathrm{TiO}_{2}$ [43] [44]. As far as we are aware, $\mathrm{TiO}_{2}$ was first used as a support in this case [43]. As the work function of $\mathrm{TiO}_{2}$ $(\sim 4.6 \mathrm{eV})$ is less than that of Pt metals $(4.7-5.7 \mathrm{eV})$, electron transfer is expected to occur from $\mathrm{TiO}_{2}$ to the deposited metals, which increases the activation of adsorbed molecules. We assume that illumination enhances the extent of this electron transfer at the interface of the two solids, leading to increased decomposition.

An important finding of this work is that the incorporation of $\mathrm{N}$ into $\mathrm{TiO}_{2}$ support enhanced the photoactivity of $\mathrm{TiO}_{2}$ (Figure 5), and particularly that of $\mathrm{M} / \mathrm{TiO}_{2}$ catalysts (Figure 6) and led to the decomposition of DME in the visible light, too. This can be attributed to the lowering of the bandgap of $\mathrm{TiO}_{2}$.

\subsection{Comparison of the Reactivity of Various Organic Compounds}

As we studied the photocatalytic decomposition of several organic compounds on the same catalysts under exactly identical experimental conditions, this gives us a possibility to make a comparison. Some data are presented in Table 4. It shows that $\mathrm{HCOOH}$ is the most reactive compound both on $\mathrm{TiO}_{2}$ and $\mathrm{Rh} / \mathrm{TiO}_{2} . \mathrm{H}_{2}$ was also formed with highest selectivity and yield in the photocatalytic decomposition of $\mathrm{HCOOH}$. Relatively high yield for $\mathrm{H}_{2}$ formation was obtained in the decomposition of $\mathrm{C}_{2} \mathrm{H}_{5} \mathrm{OH}$ on $\mathrm{Rh} / \mathrm{TiO}_{2}$.

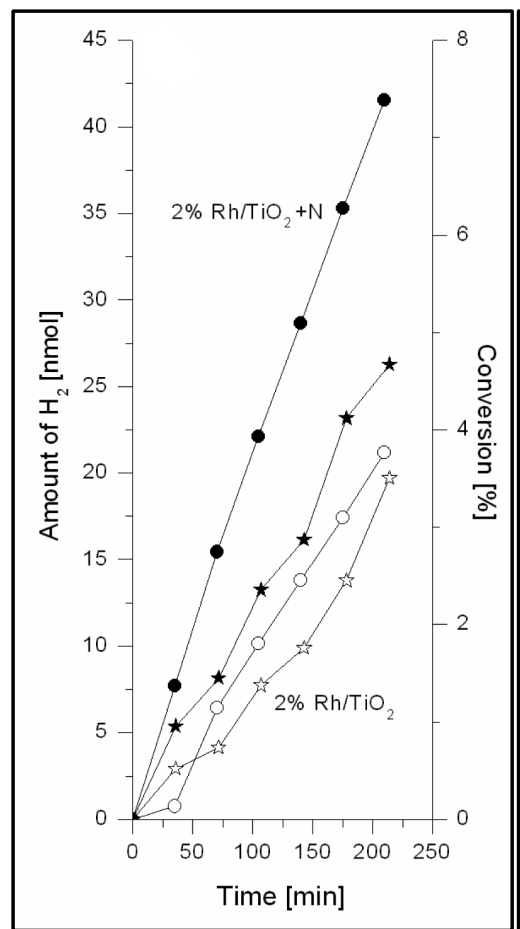

(a)

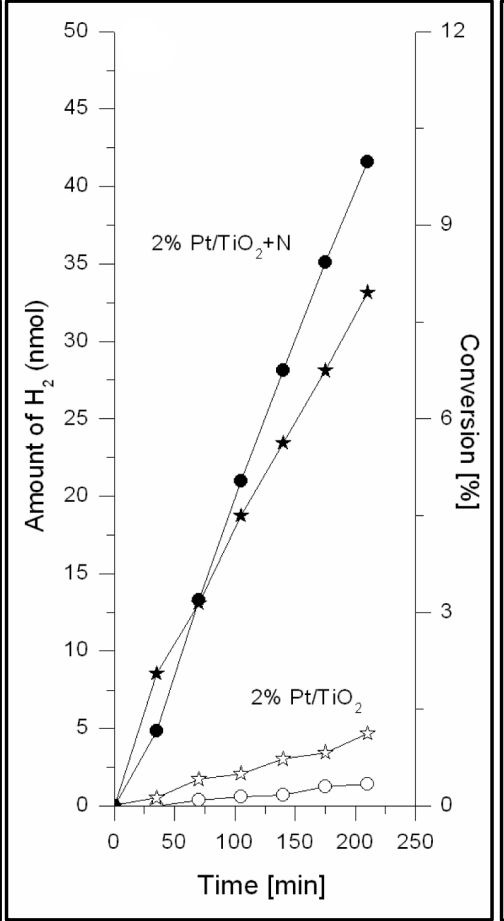

(b)

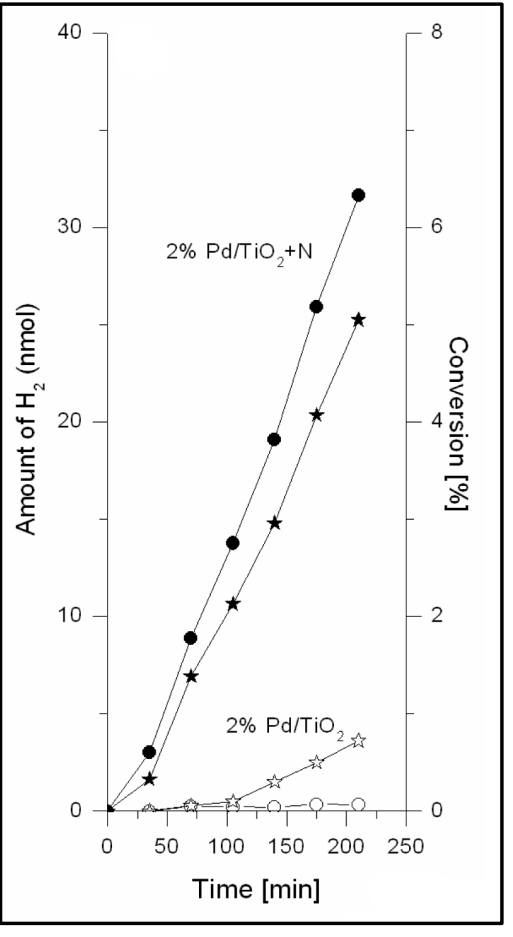

(c)

Figure 6. Effects of $\mathrm{N}$-doping of $\mathrm{TiO}_{2}(\mathrm{SX})$ on the photocatalytic decomposition of dimethyl ether on $2 \% \mathrm{Rh} / \mathrm{TiO} \mathrm{O}_{2}(\mathrm{a})$, $2 \% \mathrm{Pt} / \mathrm{TiO}_{2}$ (b), and $2 \% \mathrm{Pd} / \mathrm{TiO}_{2}$ (c) in visible light. $\circ$ خ $\mathrm{TiO}_{2}, \bullet \star \mathrm{TiO}_{2}+\mathrm{N}$, « $\star$ conversion, $\circ \bullet \mathrm{H}_{2}$ formation. 
Table 4. Comparison of the results obtained in the photocatalytic decomposition of various compounds.

\begin{tabular}{ccccccc}
\hline & \multicolumn{3}{c}{$\mathrm{TiO}_{2}$} & \multicolumn{3}{c}{$2 \% \mathrm{Rh}^{2} / \mathrm{TiO}_{2}$} \\
\cline { 2 - 7 } Compounds & conversion (\%) & $\mathrm{S}_{\mathrm{H}_{2}}$ & yield for $\mathrm{H}_{2}$ & conversion (\%) & $\mathrm{S}_{\mathrm{H}_{2}}$ & yield for $\mathrm{H}_{2}$ \\
\hline $\mathrm{HOOOH}$ & 32.1 & 90.4 & 29.0 & 100 & 99.9 & 99.9 \\
$\mathrm{CH}_{3} \mathrm{OH}$ & 8.0 & 7.6 & 0.6 & 42 & 61.6 & 25.8 \\
$\mathrm{C}_{2} \mathrm{H}_{5} \mathrm{OH}$ & 3.8 & - & - & 92.5 & 44.2 & 40.8 \\
$\mathrm{DME}$ & 3.5 & - & - & 22 & 87.5 & 19.3 \\
\hline
\end{tabular}

\section{Conclusions}

- IR spectroscopic study revealed that a fraction of adsorbed DME underwent the dissociation to methoxy species on $\mathrm{TiO}_{2}$ at $300 \mathrm{~K}$.

- Illumination of adsorbed DME leads to the generation of formate species, and to the formation of CO bonded to Pt metals.

- Photocatalytic decomposition of $\mathrm{DME}$ on $\mathrm{TiO}_{2}$ is a very limited process.

- Deposition of Pt metals on $\mathrm{TiO}_{2}$ markedly enhanced the extent of photocatalytic reaction.

- Lowering the bandgap of $\mathrm{TiO}_{2}$ by $\mathrm{N}$ doping appreciably increased the photocatalytic activity of metal/ $/ \mathrm{TiO}_{2}$ catalysts.

\section{Acknowledgements}

This work was supported by the grant OTKA under contract number K 81517 and TÁMOP under contract number 4.2.2.A-11/1/KONV-2012-0047.

\section{References}

[1] Sandstede, G. (1992) Decomposition of Hydrocarbons into Hydrogen and Carbon for the $\mathrm{CO}_{2}$-Free Production of Hydrogen. 9th World Hydrogen Energy Conference, Paris, 22-25 June 1992, 1745.

[2] Haryanto, A., Fernando, S., Murali, N. and Adhikari, S. (2005) Current Status of Hydrogen Production Techniques by steam Reforming of Ethanol: A Review. Energy Fuels, 19, 2098-2106. http://dx.doi.org/10.1021/ef0500538

[3] Muradov, N. (2001) Catalysis of Methane Decomposition over Elemental Carbon. Catalysis Communications, 2, 89-94. http://dx.doi.org/10.1016/S1566-7367(01)00013-9

[4] Mariňo, F., Boveri, M., Baronetti, G. and Laborde, M. (2001) Hydrogen Production from Steam Reforming of Bioethanol Using $\mathrm{Cu} / \mathrm{Ni} / \mathrm{K} / \gamma-\mathrm{Al}_{2} \mathrm{O}_{3}$ Catalysts. Effect of Ni. International Journal of Hydrogen Energy, 26, 665-668. http://dx.doi.org/10.1016/S0360-3199(01)00002-7

[5] Diagne, C., Idriss, H. and Kiennemann, A. (2002) Hydrogen Production by Ethanol Reforming over $\mathrm{Rh} / \mathrm{CeO}_{2}-\mathrm{ZrO} 2$ Catalysts. Catalysis Communications, 3, 565-571. http://dx.doi.org/10.1016/S1566-7367(02)00226-1

[6] Ojeda, M. and Iglesia, E. (2009) Formic Acid Dehydrogenation on Au-Based Catalysts at Near-Ambient Temperatures. Angewandte Chemie International Edition, 48, 4800-4803. http://dx.doi.org/10.1002/anie.200805723

[7] Koós, Á. and Solymosi, F. (2010) Production of CO-free $\mathrm{H}_{2}$ by Formic Acid Decomposition over $\mathrm{MO}_{2} \mathrm{C} / \mathrm{Carbon}$ Catalysts. Catalysis Letters, 138, 23-27. http://dx.doi.org/10.1007/s10562-010-0375-3

[8] Bulushev, D.A., Beloshapkin, S. and Ross, J.R.H. (2010) Hydrogen from Formic Acid Decomposition over Pd and Au Catalysts. Catalysis Today, 154, 7-12. http://dx.doi.org/10.1016/j.cattod.2010.03.050

[9] Zhou, X., Huang, Y., Xing, W., Liu, C., Liao, J. and Lu, T. (2008) High-Quality Hydrogen from the Catalyzed Decomposition of Formic Acid by Pd-Au/C and Pd-Ag/C. Chemical Communications, 3540-3542. http://dx.doi.org/10.1039/b803661f

[10] Solymosi, F., Koós, Á., Liliom, N. and Ugrai, I. (2011) Production of CO-free $\mathrm{H}_{2}$ from Formic Acid. A Comparative Study of the Catalytic Behaviour of Pt Metals on a Carbon Support. Journal of Catalysis, 279, 213-219. http://dx.doi.org/10.1016/j.jcat.2011.01.023

[11] Gazsi, A., Bánsági, T. and Solymosi, F. (2011) Decomposition and Reforming of Formic Acid on Supported Au Catalysts: Production of CO-Free $\mathrm{H}_{2}$. Journal of Physical Chemistry C, 115, 15459-15466. http://dx.doi.org/10.1021/jp203751w 
[12] Linsebigler, A., Lu, G. and Yates, Jr., J.T. (1995) Photocatalysis on $\mathrm{TiO}_{2}$ Surfaces: Principles, Mechanisms, and Selected Results. Chemical Reviews, 95, 735-758. http://dx.doi.org/10.1021/cr00035a013

[13] Hoffmann, M.R., Martin, S.T., Choi, W. and Bahnemann, D.W. (1995) Environmental Applications of Semiconductor Photocatalysis. Chemical Reviews, 95, 69-96. http://dx.doi.org/10.1021/cr00033a004

[14] Halasi, Gy., Schubert, G. and Solymosi, F. (2012) Photodecomposition of Formic Acid on N-Doped and Metal-Promoted $\mathrm{TiO}_{2}$. Production of CO-Free $\mathrm{H}_{2}$. Journal of Physical Chemistry C, 116, 15396-15405. http://dx.doi.org/10.1021/jp3030478

[15] Galvita, V.V., Semin, G.L., Belyaev, V.D., Yurieva, T.M. and Sobyanin, V.A. (2001) Production of Hydrogen from Dimethyl Ether. Applied Catalysis A: General, 216, 85-90. http://dx.doi.org/10.1016/S0926-860X(01)00540-3

[16] Takeishi, K. and Suzuki, H. (2004) Steam Reforming of Dimethyl Ether. Applied Catalysis A: General, 260, $111-117$. http://dx.doi.org/10.1016/j.apcata.2003.10.006

[17] Nishiguchi, T., Oka, K., Matsumoto, T., Kanai, H., Utani, K. and Imamura, S. (2004) Durability of $\mathrm{WO}_{3} / \mathrm{ZrO}_{2}-$ $\mathrm{CuO} / \mathrm{CeO}_{2}$ Catalysts for Steam Reforming of Dimethyl Ether. Applied Catalysis A: General, 301, 66-74. http://dx.doi.org/10.1016/j.apcata.2005.11.011

[18] Faungnawakij, K., Tanaka, Y., Shimoda, N., Fukunaga, T., Kawashima, S., Kikuchi, R. and Eguchi, K. (2006) Influence of Solid-Acid Catalysts on Steam Reforming and Hydrolysis of Dimethyl Ether for Hydrogen Production. Applied Catalysis A: General, 304, 40-48. http://dx.doi.org/10.1016/j.apcata.2006.02.021

[19] Kawabata, T., Matsuoka, H., Shishido, T., Li, D., Tian, Y., Sano, T. and Takehira, K. (2006) Steam Reforming of Dimethyl Ether over ZSM-5 Coupled with $\mathrm{Cu} / \mathrm{ZnO} / \mathrm{Al}_{2} \mathrm{O}_{3}$ Catalyst Prepared by Homogeneous Precipitation. Applied Catalysis A: General, 308, 82-90. http://dx.doi.org/10.1016/j.apcata.2006.04.032

[20] Semelsberger, T.A., Ott, K.C., Borup, R.L. and Greene, H.L. (2005) Generating Hydrogen-Rich Fuel-Cell Feeds from Dimethyl Ether (DME) Using Physical Mixtures of a Commercial $\mathrm{Cu} / \mathrm{Zn} / \mathrm{Al}_{2} \mathrm{O}_{3}$ Catalyst and Several Solid-Acid Catalysts. Applied Catalysis B: Environmental, 65, 291-300. http://dx.doi.org/10.1016/j.apcatb.2006.02.015

[21] Fukunaga, T., Ryomon, N. and Shimazo, S. (2008) The Influence of Metals and Acidic Oxide Species on the Steam Reforming of Dimethyl Ether (DME). Applied Catalysis A: General, 348, 193-200. http://dx.doi.org/10.1016/j.apcata.2008.06.031

[22] Solymosi, F., Barthos, R. and Kecskeméti, A. (2008) The Decomposition and Steam Reforming of Dimethyl Ether on Supported $\mathrm{Mo}_{2} \mathrm{C}$ Catalysts. Applied Catalysis A: General, 350, 30-37. http://dx.doi.org/10.1016/j.apcata.2008.07.037

[23] Halasi, Gy., Bánsági, T. and Solymosi, F. (2009) Production of Hydrogen from Dimethyl Ether over Supported Rhodium Catalysts. ChemCatChem, 1, 311-317. http://dx.doi.org/10.1002/cctc.200900113

[24] Faungnawakij, K., Shimoda, N., Fukunaga, T., Kikuchi, R. and Eguchi, K. (2009) Crystal Structure and Surface Species of $\mathrm{CuFe}_{2} \mathrm{O}_{4}$ Spinel Catalysts in Steam Reforming of Dimethyl Ether. Applied Catalysis B: Environmental, 92, 341-350. http://dx.doi.org/10.1016/j.apcatb.2009.08.013

[25] Gazsi, A., Ugrai, I. and Solymosi, F. (2011) Production of Hydrogen from Dimethyl Ether on Supported Au Catalysts. Applied Catalysis A: General, 391, 360-366. http://dx.doi.org/10.1016/j.apcata.2010.04.054

[26] Rouhi, A.M. (1995) Underwater Chemistry Creates Massive Sea-Floor Mineral Deposits. Chemical \& Engineering News, 73, 37-39. http://dx.doi.org/10.1021/cen-v073n050.p037

[27] Fleish, T.H., Basu, A., Gradassi, M.J. and Masin, J.G. (1997) Dimethyl Ether: A Fuel For The 21st Century. Studies in Surface Science and Catalysis, 107, 117-125. http://dx.doi.org/10.1016/S0167-2991(97)80323-0

[28] Olah, G.A. and Molnár, Á. (2003) Hydrocarbon Chemistry. Wiley, New York. http://dx.doi.org/10.1002/0471433489

[29] Kecskeméti, A., Barthos, R. and Solymosi, F. (2008) Aromatization of Dimethyl Ether and Diethyl Ether on Mo 2 CPromoted ZSM-5 Catalysts. Journal of Catalysis, 258, 111-120.

[30] Wu, M.C., Tóth, G., Sápi, A., Leino, A.R., Kónya, Z., Kukovecz, Á., Su, W.F. and Kordás, K. (2012) Synthesis and Photocatalytic Performance of Titanium Dioxide Nanofibers and the Fabrication of Flexible Composite Films from Nanofibers. Journal of Nanoscience and Nanotecnology, 12, 1421-1424. http://dx.doi.org/10.1166/jnn.2012.4655

[31] Xu, J.H., Dai, W.L., Li, J., Cao, Y., Li, H., He, H. and Fan, K. (2008) Simple Fabrication of Thermally Stable Apertured N-doped $\mathrm{TiO}_{2}$ Microtubes as a Highly Efficient Photocatalyst under Visible Light Irradiation. Catalysis Communications, 9, 146-152. http://dx.doi.org/10.1016/j.catcom.2007.05.043

[32] Schubert, G., Bánsági, T. and Solymosi, F. (2013) Photocatalytic Decomposition of Methyl Formate over TiO $\mathrm{T}_{2}$-Supported Pt Metals. Journal of Physical Chemistry C, 117, 22797-22804. http://dx.doi.org/10.1021/jp406840n

[33] Beebe Jr., T.P., Crowell, J.E. and Yates Jr., J.T. (1988) Reaction of Methyl Chloride with Alumina Surfaces: A Study of the Methoxy Surface Species by Transmission Infrared Spectroscopy. Journal of Physical Chemistry, 92, 1296-1301. http://dx.doi.org/10.1021/j100316a056 
[34] Chen, J.G., Basu, P., Ballinger, T.H. and Yates Jr., J.T. (1989) A Transmission Infrared Spectroscopic Investigation of the Reaction of Dimethyl Ether with Alumina Surfaces. Langmuir, 5, 352-356. http://dx.doi.org/10.1021/la00086a011

[35] Busca, G., Elmi, A.S. and Forzatti, P. (1987) Mechanism of Selective Methanol Oxidation over Vanadium Oxide-Titanium Oxide Catalysts: A FT-IR and Flow Reactor Study. Journal of Physical Chemistry, 91, 5263-5269. http://dx.doi.org/10.1021/j100304a026

[36] Solymosi, F. and Pásztor, M. (1986) Infrared Study of the Effect of $\mathrm{H}_{2}$ on CO-Induced Structural Changes in Supported Rh. Journal of Physical Chemistry, 90, 5312-5317. http://dx.doi.org/10.1021/j100412a081

[37] Solymosi, F. and Klivényi, G. (1993) HREELS Study of $\mathrm{CH}_{3} \mathrm{I}$ and $\mathrm{CH}_{3}$ Adsorbed on Rh(111) Surface. Journal of Electron Spectroscopy and Related Phenomena, 64-65, 499-506. http://dx.doi.org/10.1016/0368-2048(93)80115-3

[38] Jenner, G. (1995) Homogeneous Catalytic Reactions Involving Methyl Formate. Applied Catalysis A: General, 121, 25-44. http://dx.doi.org/10.1016/0926-860X(95)85008-2

[39] Kominami, H., Sugahara, H. and Hashimoto, K. (2010) Photocatalytic Selective Oxidation of Methanol to Methyl Formate in Gas Phase over Titanium(Iv) Oxide in a Flow-Type Reactor. Catalysis Communications, 11, 426-429. http://dx.doi.org/10.1016/j.catcom.2009.11.014

[40] Halasi, G., Schubert, G. and Solymosi, F. (2012) Comparative Study on the Photocatalytic Decomposition of Methanol on $\mathrm{TiO}_{2}$ Modified by N and Promoted by Metals. Journal of Catalysis, 294, 199-206. http://dx.doi.org/10.1016/j.jcat.2012.07.020

[41] Phillips, K.R., Jensen, S.C., Baron, M., Li, S.C. and Friend, C.M. (2013) Sequential Photo-Oxidation of Methanol to Methyl Formate on $\mathrm{TiO}_{2}(110)$. Journal of American Chemical Society, 135, 574-577. http://dx.doi.org/10.1021/ja3106797

[42] Connelly, K., Wahab, A.K. and Idriss, H. (2012) Photoreaction of $\mathrm{Au} / \mathrm{TiO}_{2}$ for Hydrogen Production from Renewables: A Review on the Synergistic Effect between Anatase and Rutile Phases of $\mathrm{TiO}_{2}$. Materials for Renewable and Sustainable Energy, 1, 3.

[43] Szabó, Z.G. and Solymosi, F. (1961) Influence of the Defect Structure of Support on the Activity of Catalyst. Actes Du Deuxieme Congres International De Catalyse, Paris, July 1960, 1627-1651.

[44] Solymosi, F. (1968) Importance of the Electric Properties of Supports in the Carrier Effect. Catalysis Reviews, 1, 233255. http://dx.doi.org/10.1080/01614946808064705 